\title{
The Role of Universities in Sustainability-Oriented Competencies Development: Insights from an Empirical Study on Polish Universities
}

\author{
Monika Sady *(D), Agnieszka Żak and Karolina Rzepka \\ Department of International Management, Faculty of Economics and International Relations, Cracow University \\ of Economics, ul. Rakowicka 27, 31-510 Krakow, Poland \\ * Correspondence: monika.sady@uek.krakow.pl
}

Received: 4 June 2019; Accepted: 21 August 2019; Published: 23 August 2019

check for updates

\begin{abstract}
The growing importance of sustainable development constitutes a challenging trend for education. Universities create study programs and organize extracurricular activities in order to prepare future generations of professionals as well as political and social leaders for responsible actions toward sustainable development. The main objective of this article is to investigate how universities in Poland develop educational programs and extracurricular activities to enable students to shape sustainability competencies. The study employed a triangulation of research methods including a literature analysis, desk research analysis of the universities' educational programs, and quantitative research among students. The findings suggest that Polish universities attempt to shape sustainable development-oriented competencies not only through formal sustainable development education, but also via non-formal activities toward social and environmental challenges. The research results have practical implications for universities and can support the advancement of educational programs related to sustainable development.
\end{abstract}

Keywords: sustainability; sustainability-oriented competencies; education for sustainability; university; Poland

\section{Introduction}

Sustainable development is a concept centered around achieving human development goals and simultaneously sustaining the ability of ecosystems by providing natural resources and protecting wildlife and nature without diminishing the chances for future generations. It is perceived as a significant concept of social and economic development since it was first defined by the World Commission on Environment and Development (WCED) of the United Nations in 1987. The report Our common future defined sustainable development as one that strives to meet the needs of present and future generations in compliance with the environment (Brundtland 1987). The WCED attempted to explore the causes of environmental degradation as well as the interconnections between social equity and economic growth. The sustainability goals integrate the three aspects of economic, societal, and environmental to ensure development for future generations.

Given the current activities at an international level, the Agenda of United Nations for Sustainable Development based on the document "Transforming Our World: The 2030 Agenda for Global Action" (United Nations 2015) was designated in 2015. The new Sustainable Development Goals (SDGs), with the prospect of 2030, emphasize among others, the relevance of higher education in endeavors toward a better future (Ramos 2016). Including the UN Sustainable Development Goals into the curriculum will support the development of future-oriented competencies. This can be achieved by promoting societal, economic, and political change, which can be supported by professional leaders and specialists. 
The latest developments also show that the European Union strategy “Europe 2020: A strategy for smart, sustainable and inclusive growth" adapted in 2010 (European Union 2010) points out the crucial importance of innovation, education, digital society, training, and lifelong learning in this context.

According to the Global Action Program on Education for Sustainable Development, adopted by UNESCO in 2014, it can be stated that political agreements, financial incentives, and modern technologies are not enough to achieve sustainable development (UNESCO 2014). Radical changes are indispensable, especially in the way of thinking and acting when shaping relationships in a social context and together with the Earth's ecosystem. In order to ensure sustainable development that will meet the needs of present and future generations, it is necessary to equip all individuals with the appropriate knowledge and skills to shape a system of sustainability-related values. Leaders of change, whose involvement and actions will evolve in the general public's awareness are necessary (Hesselbarth and Schaltegger 2014).

In the literature, numerous research has been already conducted on human resource management, responsible leadership, employee well-being, and job satisfaction in the context of responsible and sustainable development in organizations (Kudłak and Low 2015). Responsible leaders, with a strong willingness to contribute to the sustainability in different organizations, might significantly influence both the strategy and the employees. They can lead employees to engage in responsible actions and behaviors that address not only internal, but also external problems of the organization (Groves and LaRocca 2011; Cameron 2011; Gond et al. 2011). Sustainable development requires a change in people's consciousness and provides a framework for further decisions and actions. In line with this, a "new culture of learning" is needed (Erpenbeck and Rosenstiel 2003) that should be focused on self-organization and competence. The purpose of education is to support the development of personality in order to manage complex situations and make appropriate decisions, bear responsibility, and have high ethical standards in accordance with the requirements of sustainable development (Urbaniec 2018).

The research objective of this article was to explore how universities in Poland develop educational programs and extracurricular activities in order to enable students to shape sustainability competencies. The study was conducted based on a triangulation of research methods including a critical literature analysis on the role of higher education in shaping sustainability competencies, a desk research analysis of the universities' educational programs, and quantitative research among students.

The article is structured as follows. The introduction explains the research background and determines the main goal of the study. In Section 2, the literature review on the role of universities in education for sustainable development and in shaping sustainability-oriented competencies is conducted. Section 3 focuses on the materials and methods used with regard to the research methodology, the chosen sampling, data collection, and analysis methods. Based on the desk research analysis of the universities' educational programs and quantitative research among students, the empirical results of the study are presented in Section 4. In Section 5, the discussion of results is provided, the main findings are summarized, and the limitations and future research are outlined.

\section{Literature Review}

There is a consensus among researchers that universities play an important role in meeting the challenges of sustainable development through education (Mochizuki and Fadeeva 2010; Boström et al. 2018; Eizaguirre et al. 2019; Sibbel 2009). Universities are considered to be change agents in many issues including sustainability awareness (Mochizuki and Fadeeva 2010). In addition to education and research, the so-called "third mission of the university" consists of working toward the improvement of people's lives and solving global problems (Miotto et al. 2018). Universities constitute a fundamental vehicle to explore, test, develop, and communicate the essential conditions for sustainable development (Salvioni et al. 2017; Disterheft et al. 2013; Leal Filho 2012) and education worldwide has become an investment which has to pay off for the student. Therefore, universities need to be reformed in the field of teaching and research (Brito et al. 2018). The role of universities in this process is essential, 
because they play a crucial role in the development of economic systems through disseminating knowledge, creating innovation, promoting sustainable development, environmental friendliness, and fostering cultural growth (Salvioni et al. 2017). Universities develop adult skills such as "problem solving, critical thinking, ability to cooperate, creativity, computational thinking, self-regulation, which are more essential than ever before in our quickly changing society." (The Council of the European Union 2018, p. 2). Universities have the possibility of using different tools to connect those skills with expert knowledge and enable students to generate new ideas, new theories, and new products evolving around sustainable development issues.

The development of sustainability-oriented competencies should be supported by improving education and introducing innovative forms of teaching and learning. Acquiring competencies is significantly different than learning (understood as knowledge acquisition) because competencies are defined as learnable, but not teachable (Weinert 2001). Numerous authors have discussed the matter of sustainable development competencies. Lozano et al. (2017) conducted a literature review and identified the following synthesis of sustainability competencies: systemic thinking; interdisciplinary work; anticipatory thinking; justice, responsibility, and ethics; critical thinking and analytical work; interpersonal relationships and collaboration; empathy and change of perspectives; communication and use of the media; strategic thinking; personal engagement; assessment and evaluation; and tolerance for ambiguity and uncertainty. Lambrechts et al. (2013), comparing the findings and definitions by De Haan (2010) and Roorda (2010), indicated six sustainability competencies: responsibility (values, ethics, reflection); emotional intelligence (transcultural understanding, empathy, solidarity, compassion); system orientation (interdisciplinarity); future orientation; personal involvement (self-motivation, motivating others, learning); and the ability to take action (participatory skills). Another typology developed by the UNESCO in the document "Education for Sustainable Development Goals. Learning Objectives" embraces similar key competencies for sustainability: systems thinking competency, anticipatory competency, normative competency, strategic competency, collaboration competency, critical thinking competency, self-awareness competency, and integrated problem-solving competency (UNESCO 2017).

Given the different types of sustainability competencies, it can be emphasized that higher education institutions are faced with enormous challenges in developing the appropriate knowledge and skills. An exemplary initiative relates to the Principles for Responsible Management Education (PRME) established in 2007 by the UN, which is increasingly adopted by business schools around the world as a framework for various programs and activities (Prandi et al. 2018). The PRME is a platform promoting sustainable development at universities around the world by providing business school students with the ability to make social and environmental changes. It underlines the necessity of "a process of continuous improvement among institutions of management education in order to develop a new generation of business leaders capable of managing the complex challenges faced by business and society in the 21st century." (PRME 2019). Universities that are members of PRME aspire to develop a range of students competencies, grouped in six key areas (PRME 2018):

- Social skills: teamwork, team building, communication skills, presentation;

- Business in the real world: stakeholder management, engagement of community needs through business, marketing, sustainability enhancement, entrepreneurship, project management;

- Personal skills: critical thinking, self-awareness, decision making, leadership, creativity, problem solving;

- Intercultural skills;

- $\quad$ Academic research, business models, planning and coordination; and

- $\quad$ Service, volunteering, empathy, social responsibility, global mindset, ethical awareness, empathy.

These competencies emphasize the need to strengthen holistic and integrated education without indicating the main priority, which is acquiring knowledge, in order to not limit other forms of learning (Urbaniec 2018). This approach is convergent with The Council of The European Union's 
recommendation (The Council of the European Union 2018) on key competencies in the lifelong learning process, where all competencies are considered equally important, and each of them contributes to a successful life in society. Competencies can be used in many different contexts and combinations. Their ranges coincide and are interrelated, for example, aspects necessary in one area support competencies in another. Skills such as critical thinking, problem solving, team work, communication and negotiation skills, analytical skills, creativity and intercultural skills are all part of key competencies (The Council of the European Union 2018).

Many scientists perceive sustainability-oriented competencies as a determinant of the effectiveness of an individual's function in society (Argyle 1983; Goleman 2006; Borkowski 2003) as these competencies have a positive effect on ones' adaptation and function in society (Żur 2016). Therefore, a sustainable future will be achieved if societies are properly educated. Enabling learners to acquire competencies in the field of sustainable development will be successful by making the present learning process more effective (by obtaining better learning results: deeper understanding, longer retainment of knowledge, solid learning) (Cerone and Persico 2014).

The dilemma of how to acquire these competencies via learning programs is of increasing relevance (Weinert 2001). As students are growing up in a world of global media, where the voices of many cultures compete for attention (De Block and Buckingham 2007), it is a challenge for lecturers to teach them to analyze, critically manage, and understand the flow of information to be able to use it for the common good. The main difficulty in sustainability education results from the multidisciplinary context, which makes the difference with regard to education in traditional disciplines. Teaching and learning in the field of sustainable development requires new approaches (Aktas et al. 2014; Sibbel 2009; Cortese 2003; Eizaguirre et al. 2019). The paradigm shift is complicated, because it should be implemented throughout the whole university system (Setó-Pamies and Papaoikonomou 2016) and therefore the crucial role of lecturers relies on the inclusion of global issues within the existing curriculums (Tarozzi and Inguaggiato 2016). It is expected that a university graduate should have entrepreneurial competencies and, at the same time, social competencies, so that they can be more competitive while finding their place in the demanding global job market (Lackéus 2015). Key business education forums and scholars debate that business studies students need more competencies related to professional business ethics and social responsibility (Blasco 2012; AACSB 2009; Beyond Grey Pinstripes 2009; EQUIS 2010; Ghoshal 2005; Sims and Felton 2005; PRME 2018).

Universities contribute to the development of sustainability competencies through both formal and non-formal education. Formal education is understood as curricular education and non-formal education consists of extracurricular activities offered by the universities (outside the official learning program) (European Commission 2012). The Council of the European Union (2018) highlights the importance of not only formal education, but also non-formal learning as crucial for acquiring experience through culture, youth work, and voluntary work as well as sporting activities. Non-formal learning greatly supports the development of essential interpersonal, communicative, and cognitive skills such as critical thinking, analytical skills, creativity, problem solving, and resilience, which facilitate young people's transition to adulthood. Active citizenship and working life are strongly connected to sustainable development (The Council of the European Union 2018).

Based on this conceptual framework, it can be assumed that education for sustainable development is a process that goes beyond acquiring knowledge and learning about theories related to sustainable development. It should be a holistic education process concentrated on searching for correlations, presenting a coherent picture of the world, and preparing to operate within it. Therefore, teaching for sustainable development must be supported by undertaking specific activities that translate into the functioning of the university and its relations with the environment (Kalinowska and Batorczak 2017). It is important that educational programs take into account the expectations of the labor market and current socio-economic and civilizational challenges, which require dialogue between academia and business. Higher education institutions play an important role not only in education, but also as promoters of changes in business practice (Jamali 2016) and as a support system for sustainability 
development in the market economy. It is important to determine the difference between sustainability being perceived as a particular aim to be reached through technical innovation and efficiency, and a normative direction that needs to be determined democratically (Holfelder 2019). The UNESCO has also indicated that education for sustainable development promotes learning to make decisions that secure the economic, environmental, and social future. Given the student's varied knowledge and attitudes toward sustainable development, it is necessary to support the implementation of sustainability in curriculums to achieve more positive perceptions, change mindsets, and form values and attitudes (Brito et al. 2018; Sammalisto et al. 2015).

Improving competencies and developing ecologically and socially friendly skills and attitudes through formal and non-formal learning are an essential part of striving for sustainable development (European Commission 2012). This is particularly visible in the area of higher education where students are prepared to enter the labor market and implement the principles of sustainable development accordingly. Therefore, it can be stated that the universities' actions in the field of formal education as well as non-formal (extracurricular) activities for sustainable development may have a positive impact on shaping competencies relevant for solving social and environmental problems.

\section{Materials and Methods}

\subsection{Research Sampling and Data Collection}

The main objective of this study was to explore how universities in Poland developed educational and extracurricular programs in order to shape sustainable development competencies. The applied research design included both the analysis of the educational programs in sustainability at Polish universities and a survey among students. The main research questions focused on determining whether there was a sustainability-oriented educational program at Polish universities as well as what kind of socially responsible activities (extracurricular) are provided for students. The research analysis allowed us to explore (1) whether Polish public universities offered students the opportunity to develop competencies that enabled them to actively meet the sustainability challenges; (2) to what extent students actually engaged in activities related to sustainable development offered by the universities; and (3) how the students perceived the development of competencies through non-formal education in the form of extracurricular activities. Furthermore, research on the most desired competencies by the business environment from the students' point of view will enrich the empirical analysis.

The research analysis was carried out in two steps. In the first step, the educational programs of Polish universities in terms of sustainable development, especially social responsibility issues, were examined based on secondary data, for example, a literature review and university websites. The research sample included all public universities in Poland that offer majors in economics and/or business studies. As a result, 23 higher education institutions (18 universities and five economic universities) were identified that are officially listed as public universities under the supervision of the Polish Ministry of Science and Higher Education (2019). The first of the examined aspects was the occurrence of courses related to sustainable development and corporate social responsibility in the educational program. Another aspect was the social responsibility engagement of the universities and their sustainable development policies as well as the number and type of socially responsible activities. The third area of research focused on the offering of postgraduate studies related to CSR (corporate social responsibility) and sustainable development.

The second step of the research analysis allowed us to explore to what extent these universities shaped students' ethical, sustainability-oriented, and responsible attitudes and how they created opportunities for the development of competencies. For this purpose, quantitative research among students at universities in Cracow in November and December 2018 was conducted. The material used for this research was collected from full-time students (approx. 86\% of respondents) and part-time students at three universities in Cracow. In total, 261 respondents participated in the survey, amongst whom women prevailed (approx. 74\%). More than half of the respondents were students between 
18-24 years old, of which 69\% students were from the Cracow University of Economics, $20.3 \%$ from Jagiellonian University, and 10.3\% from the AGH University of Science and Technology. Given the type of studies, the most respondents were bachelor students $(69.4 \%)$ and master students $(20.1 \%)$. Postgraduate students (8.5\%), MBA students $(1.2 \%)$, and $\mathrm{PhD}$ students $(0.8 \%)$ also participated in the survey. The research sample included students not older than 40 years old. The sample was selected using the non-random selection method, which is characterized by choosing a sample according to the investigator's subjective assessment or choice at random. It does not require expert knowledge and qualifications, and does not allow for the level of error nor the level of accuracy of the estimates to be determined (Szreder 2004).

\subsection{Research Methods}

The study employed a triangulation of research methods. The empirical research analysis was conducted by using both desk research analysis of the universities' educational offers as well as quantitative research among students. Aside from the desk research, as described in the previous subsection, a quantitative research analysis was carried out by using a survey. The research was based on computer assisted web interviewing (CAWI) by applying a standardized questionnaire. This technique was chosen due to a number of advantages that include the reduction of costs and time related to the implementation of the study. Moreover, the CAWI method creates conditions for anonymity, which may positively affect the reliability of answers as well as the opportunity to obtain answers to problematic or embarrassing questions. The limitations of this technique include the lack controlling the disturbing factors as well as lack of confidence in the credibility of the respondents and the reliability of their responses (Owens 2002). The choice of this method was justified because it allowed us to identify the motives and activities from the point of view of Polish students as well as verify the sustainability competencies available in the literature as part of the analysis conducted on the example of a selected group of students from Cracow's universities.

The application of a quantitative research method based on a survey was an appropriate approach and developed in several phases to ensure validity and reliability. First, a comprehensive literature review on subjects related to the research area was carried out to provide a basis for selecting items to be included in the questionnaire. The proper definition and operationalization of the research issues was important to provide the validity of the concepts. The evaluation criteria for the research methodology included internal, face, and external validity (Babbie 2013). Internal validity is the approximate truth about inferences regarding cause-effect (causal) relationships (Cook and Campbell 1979). In this study, on one hand, the importance of non-formal activities from the students' point of view was explored (cause), and on the other hand, their impact on shaping the sustainability competencies (effect) was analyzed. The basis for the development of the questionnaire was the PRME competencies set presented in Section 2, which was adapted to the needs of the research objective in this article. Moreover, face validity describes how respondents perceive the survey and whether-from their point of view-it is adequate to the goal it should achieve. For the surveyed respondents, the tool retained its validity and allowed us to achieve the research goal. Finally, external validity is considered as a generalizability of the research results (Crowther and Lancaster 2008). Due to the non-random selection and not representative size of the sample, the research findings could not be used to describe all students at public universities in Poland. However, the research analysis exemplified by selected Polish students provides new insights into the development of sustainability-related knowledge, skills, and attitudes. It is also a preliminary attempt at the empirical verification of sustainable development oriented competencies defined on the basis of the literature on the subject. In order to increase the validity of the research results, a triangulation of research methods was applied including the literature analysis, desk research of the educational offers of the universities, and quantitative research among the students.

Given the reliability, as a second evaluation criterion for the research methodology, it can be stated that the questionnaire used support re-examination, and thus created the possibility of replication. This is 
especially important in providing the reliability of the research analysis (Crowther and Lancaster 2008). The questionnaire used in the study consisted of open, closed, semi-open, filtering, and metric questions. Several scales were used including the dichotomous scale, nominal scale, where respondents indicated a response from a previously developed set, and the balanced scale. This supported the formulation of questions in order to collect data for analysis and interpretation. A proof was made and various bias was taken under consideration. The questionnaire was anonymous and the researchers did not influence the respondents' answers in any way. Furthermore, it should be emphasized that the use of a triangulation of research methods in this article allowed us to answer the main research question of how universities contribute to the development of sustainability competencies.

\section{Results}

\subsection{Sustainability-Oriented Offer at Polish Universities}

The educational offers of universities was based on desk research of the official data published by the universities chosen for the analysis. The majority of examined universities (70\%) created a wide range of formal education possibilities by offering courses related to the CSR area, e.g., corporate social responsibility or business ethics, or they included sustainability issues in other courses. These courses are addressed at bachelor, master, and postgraduate students. Students from faculties related to economics, management, and social sciences were most likely $(60 \%)$ to participate in such courses offered by the universities (Table 1).

Table 1. Formal educational offers on sustainable development and CSR at Polish universities.

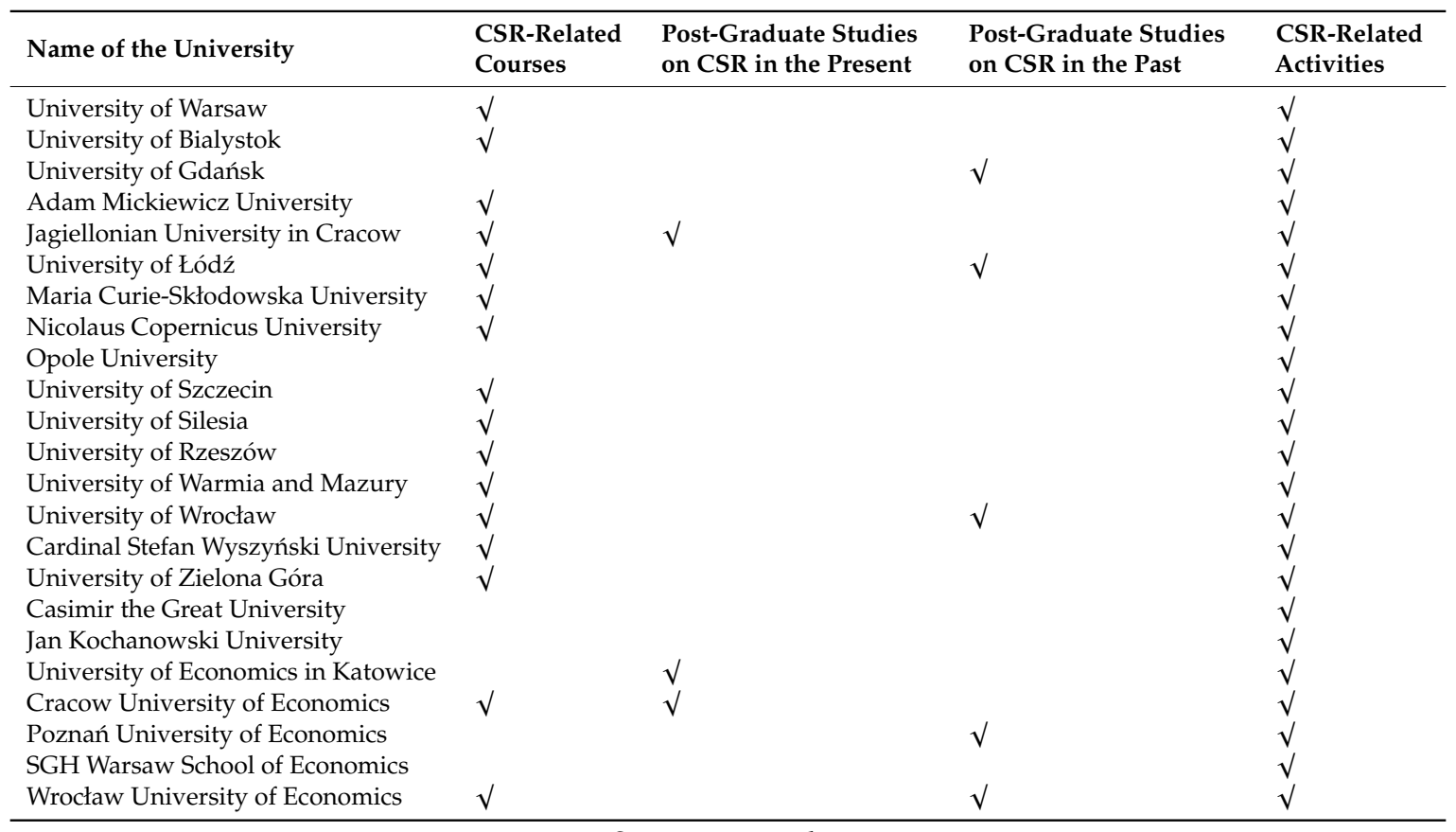

Source: own study.

A growing number of universities provide education not only for students, but also for children, youth, and seniors. Among the universities studied, $26 \%$ have established so called Universities of the Third Age, which are important centers for activating seniors. The Children's Universities, available only at $13 \%$ of the universities, are slightly less popular. In this regard, the University of Economics in Katowice can be mentioned, which, apart from the Economic University of the Third Age and the Economic Children's University, also runs the Academy of the Young Economist and additional classes for high school students. 
Despite the visible involvement of universities in the educational programs to shape the sustainable development competencies, extensive research analysis showed that only three of the 23 universities provided postgraduate studies in CSR and sustainability. For instance, the Jagiellonian University offers a Social Investment Management major to postgraduate students and the Cracow School of Business (entity of the Cracow University of Economics) provides postgraduate education in the field of Corporate Social Responsibility in Management. Similar offers in the field of corporate social responsibility have also been introduced at the University of Economics in Katowice.

Given the universities' engagement in social responsibility issues, universities also offer non-formal (extracurricular) activities and support socially responsible actions. The main difference between them is the number and type of activities. The most popular activities are blood donations and bone marrow donations as $100 \%$ of the examined universities organize them regularly. Students also have the opportunity to be involved in organizing donations for charity organizations during the Christmas season. In addition, the organized events at the universities most frequently concerned issues of environmental and animal protection, health and safety as well as equality and social inequalities.

Considering the promotion of volunteering among the academic community, it was noted that only $13 \%$ of the universities participating in the study created special organizational units for volunteering activities. In eight out of 23 institutions, there are also student organizations associated with volunteers. For instance, within the initiatives of the University of Warsaw, the Academic Legal Clinic and the Law Clinic were established to offer services related to the provision of free legal advice by law students to other students and indigent people.

\subsection{Respondents' Perception Regarding the Non-Formal Education in Sustainability and Social Responsibility}

The aim of the survey was to investigate whether students actually engaged in activities related to sustainable development offered by the universities and how they perceived the shaping of competencies through non-formal education. The conducted analysis of the students' perception about the universities' offers did not differentiate the respondents by age, sex, or type of studies. One exception were the questions in which a differentiation of answers was valuable for the analysis.

The survey among Polish students showed that competencies could be developed through participation in various activities. The first question related to the issue of whether the university offered opportunities to engage students in extracurricular activities (understood as all activities outside the curriculum including social, charitable, organizational, and scientific actions). The majority of respondents $(67.8 \%)$ replied that there was a broad spectrum of activities were available. Nearly $21 \%$ declared that they saw limited opportunities to participate in such activities and $8 \%$ were unable to answer this question because of lack of knowledge or interest in this matter. Only $3.5 \%$ of respondents indicated that the university did not create opportunities to engage students in additional activities. Several respondents explained that their lack of involvement was mainly due to a lack of time, distance, and professional work (Figure 1). It is worth noting that almost two thirds of the respondents were people aged over 30 years of age (master's degree and MBA students).

The next question focused on the current engagement of the surveyed students. The difference between the number of respondents involved and the number of students not participating in the extracurricular activities was relatively small. Almost $53 \%$ of respondents took part in such activities offered by the universities. The respondents positively evaluated the university's offers that enabled them to engage in non-curricular activities. However, each student individually decided whether to participate in those activities or not. Among all of the respondents who were aware of their university's activities, only $66.7 \%$ decided to participate in them. 


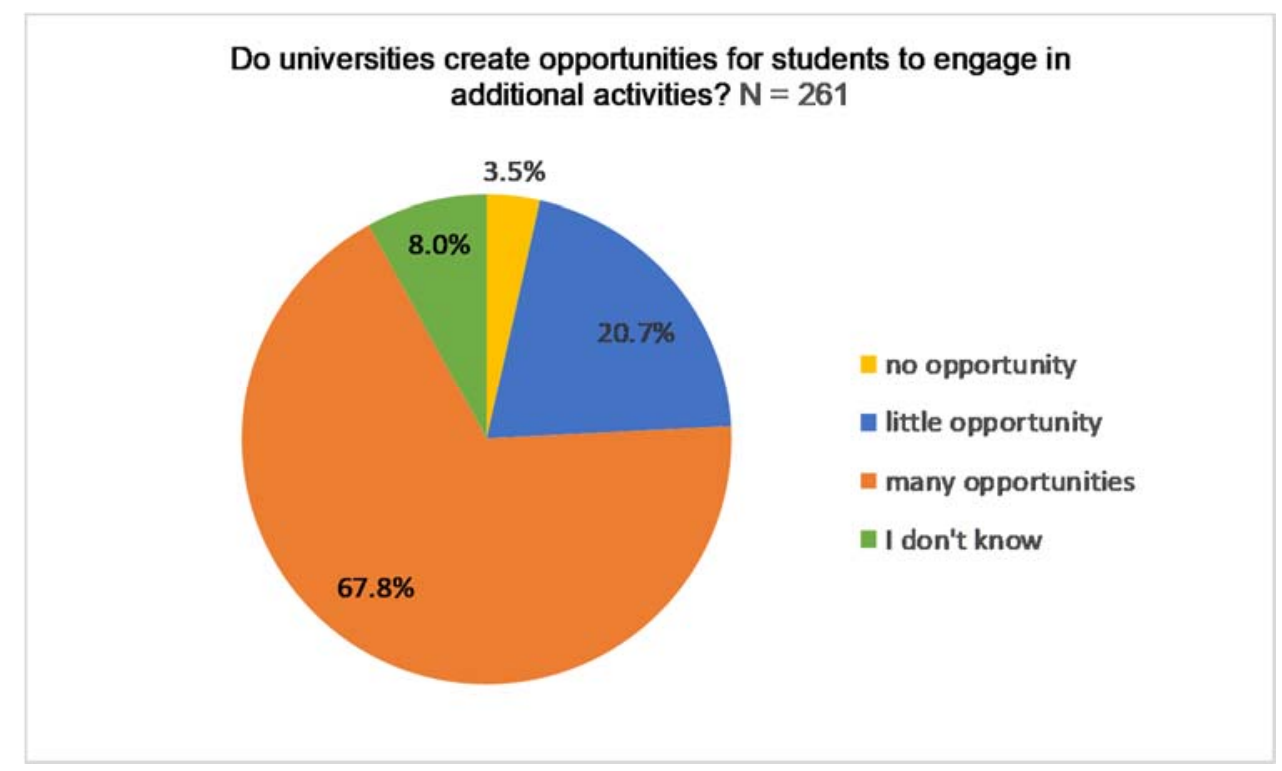

Figure 1. Student perceptions of extracurricular opportunities created by universities.

The results of the survey do not indicate any significant gender differentiation; more than half of women (53\%) and men (51\%) took part in the additional activities offered by universities. The data gathered in the study suggest that the longer the respondents study, the larger their engagement. The percentage of respondents involved in additional activities during their first year was only $36 \%$, whereas for respondents between their second and fourth year, the involvement increased to $52 \%$ and $64 \%$, respectively (Figure 2 ). This may result from the need of initial adaptation to a new place of education, engaging in the learning process, or the lack of initial information on various activities. One exception is the first year of master's studies where $40 \%$ of the respondents took part in extracurricular activities offered by the universities. This may be caused by their maturity and awareness of market expectations, and in some cases, their experiences from their bachelor studies. In turn, during the second year of master's studies, we observed an increase in the involvement in extracurricular activities of up to $56 \%$.

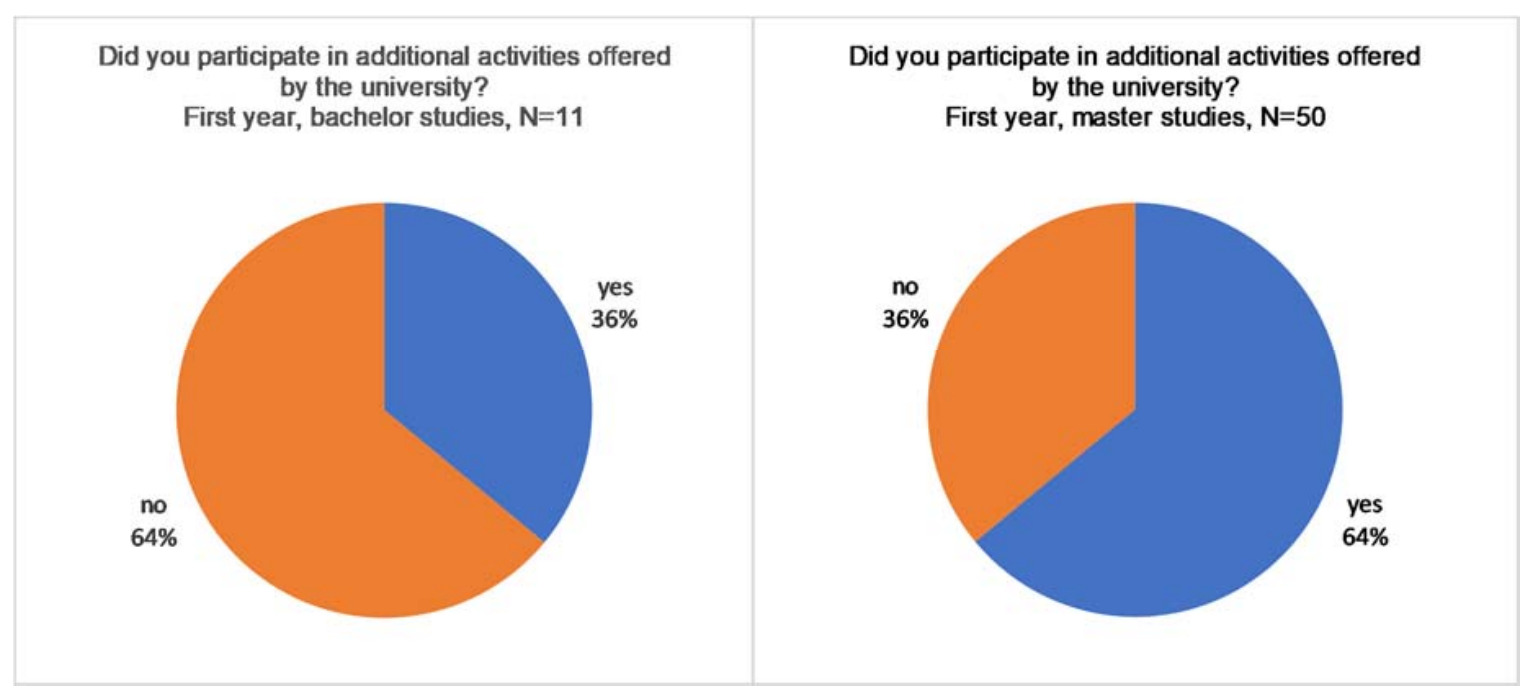

Figure 2. Students' participation in extracurricular activities offered by the university. 
Respondents who were involved in extracurricular activities during their studies were asked to specify which additional activities they participated in and could choose more than one answer. The most frequent answers were: volunteering (30\%), students' research clubs and students' organizations $(27 \%)$, and organizing events at the university (25\%). Other activities such as language courses, science fairs, and integration trips were mentioned only marginally.

Respondents were also asked about their membership in student organizations. Engagement in various types of organizations (scientific, sports, or international) enables the development of a number of PRME competencies. These include social skills such as teamwork and communication skills, cooperation with stakeholders, and strengthening sustainability and entrepreneurship. Engagement in international organizations (e.g., AIESEC or Erasmus Student Network, ESN) and cooperation with students from other cultures develops intercultural skills. Teamwork contributes to shaping personal competencies like decision-making, leadership, creativity, problem solving and empathy, social responsibility, and ethical awareness. The data obtained from this part of the study were not optimistic. Over $65 \%$ of the respondents were not a member of any student organization. Nearly $18.4 \%$ belonged to student research clubs, but other organizations were represented by a small number of respondents (e.g., ESN-nearly 5\%, Academic Sports Union-4.2\%, Independent Students' Association-3.8\%, AIESEC-3.4\%, and Students' Parliament-3.1\%).

The next question focused on the motivation of respondents to take part in extracurricular activities offered by the university (Figure 3). Among the most frequent motivation was the need for self-development (over $60 \%$ of answers), the desire to develop already acquired skills and meet new people ( $54 \%$ of answers, respectively) as well as an interest in gaining experience $(50 \%)$. The need to enrich one's resume (approx. $45 \%$ ) and to do good to others (over $40 \%$ ) were also quite common answers. Undoubtedly, all of the above-mentioned motives contribute to the development of competencies supporting sustainable development. For example, due to the need for self-development, social and personal skills (such as teamwork, empathy, and ethical awareness) are increasingly important due to volunteering activities.

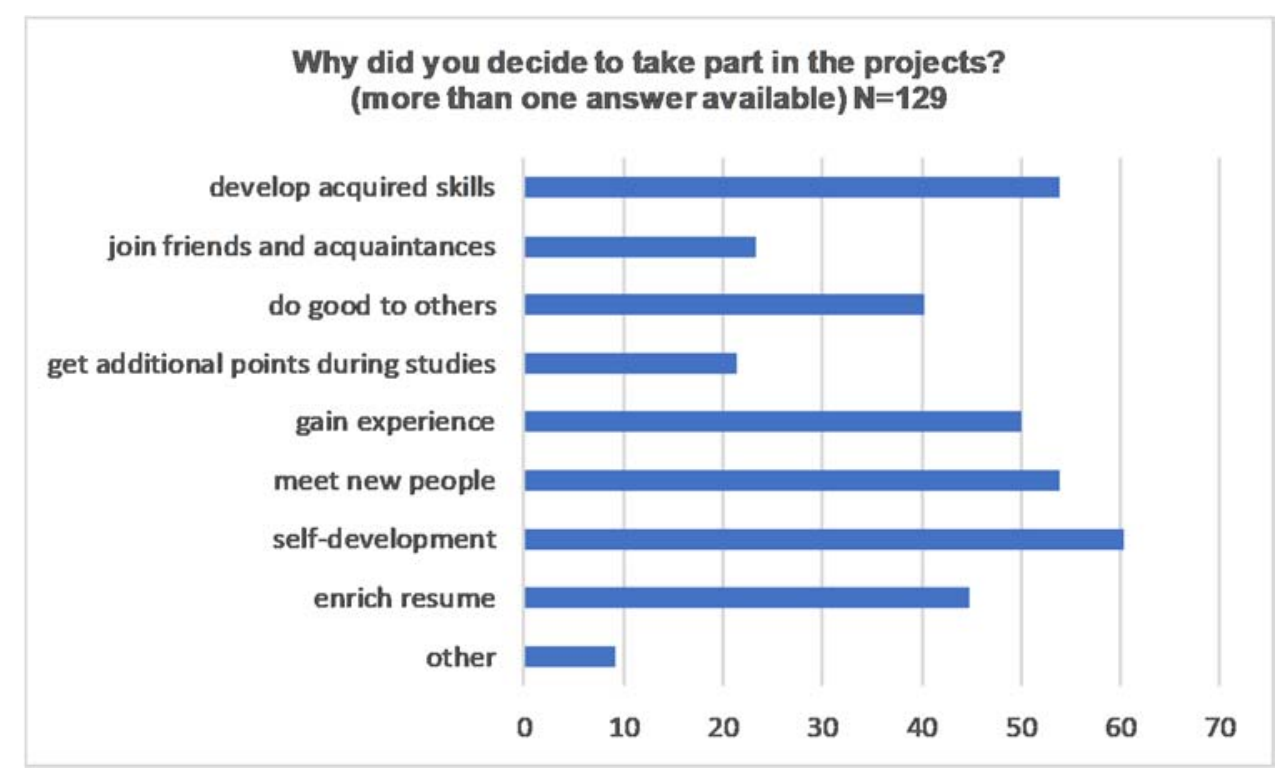

Figure 3. Motives for participating in extracurricular projects.

The next part of the survey focused on the respondents' participation in courses, training, and workshops with the intention of developing their competencies. Participation in such activities from outside the curriculum can contribute to the development of competencies that are most desired by the business environment (e.g., teamwork or solving problems). Nearly $63 \%$ of the studied population declared their participation in this type of extracurricular activity. The assessment of the university's 
capacity to develop these competencies is not clear. A positive assessment was given by nearly half of the respondents. The respondents evaluated the possibility of developing these competencies as very high (nearly $9 \%$ of respondents), sufficient (over 37\%), and 17\% assessed them as low ("none" and "poor"). Additionally, over one third of respondents (37\%) considered the offer of such opportunities as partial. The analysis of the respondents' answers also showed that over half of the respondents $(56 \%)$ who negatively assessed the activities of universities in the scope of creating opportunities for competencies development did not participate in any trainings and courses. The most effective forms of developing competency were workshops with practitioners $(75.5 \%)$, engagement in projects $(58.2 \%)$, and certified training (54.4\%). Significantly fewer respondents mentioned study visits in enterprises $(31 \%)$, activities outside of their university (29.5\%), and charity work (18.8\%) (Figure 4).

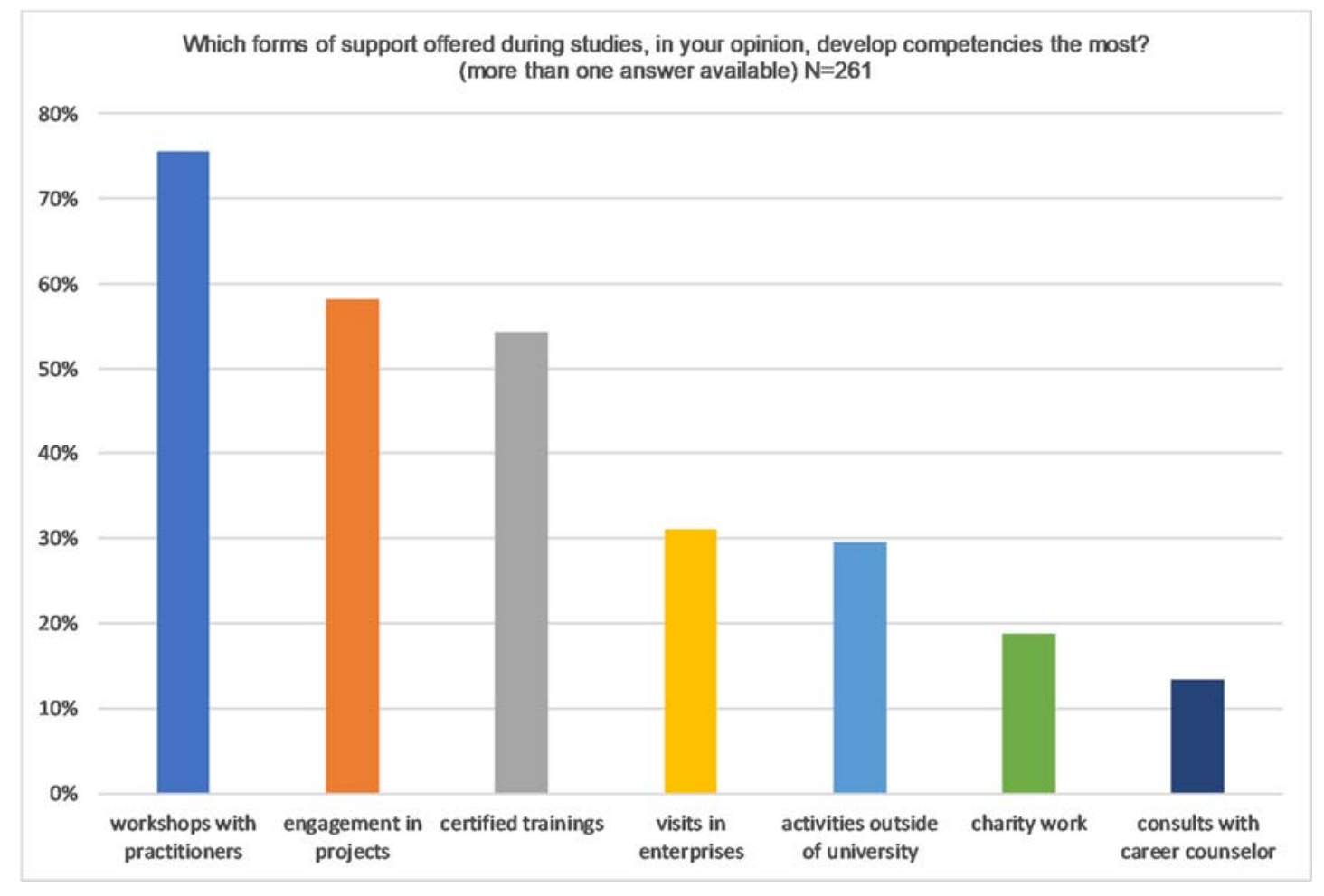

Figure 4. Extracurricular activities supporting the development of competency.

The respondents were also asked which competencies should be further developed. The following competencies were most often indicated:

- $\quad$ knowledge of foreign languages $(26 \%)$,

- computer and programming skills (more than $14 \%$ ),

- favorable self-presentation and image-building skills (around 14\%),

- $\quad$ industry and directional knowledge (11.5\%), and

- $\quad$ assertiveness (nearly 10\%).

The respondents planned to take additional actions to develop their competencies (Figure 5), for example, by participating in courses, training, and workshops ( $66 \%$ of respondents), postgraduate studies (21\%), studying another major (14\%), and MBA studies (nearly $8 \%$ ). A total of $15 \%$ of the population did not plan to invest in additional competency development in the near future. 


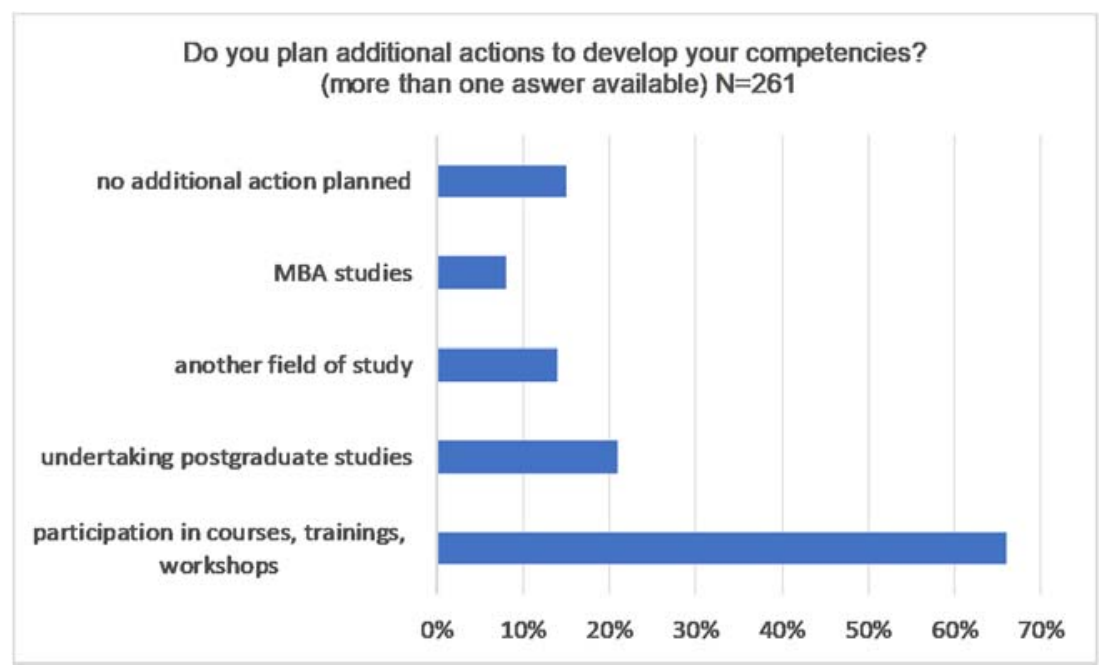

Figure 5. The respondents' plans concerning additional actions for competency development.

\subsection{Impact of Non-Formal Education on Sustainability Competencies}

To investigate this issue more deeply, respondents were also asked how their involvement in extracurricular activities influenced the development of particular competencies useful from the point of view of sustainable development. Among the most developed competencies the respondents listed were flexibility and the ability to adapt, openness to learning and continuous development, teamwork and responsibility, effective verbal and non-verbal communication, and the ability to formulate and solve problems (Figure 6).

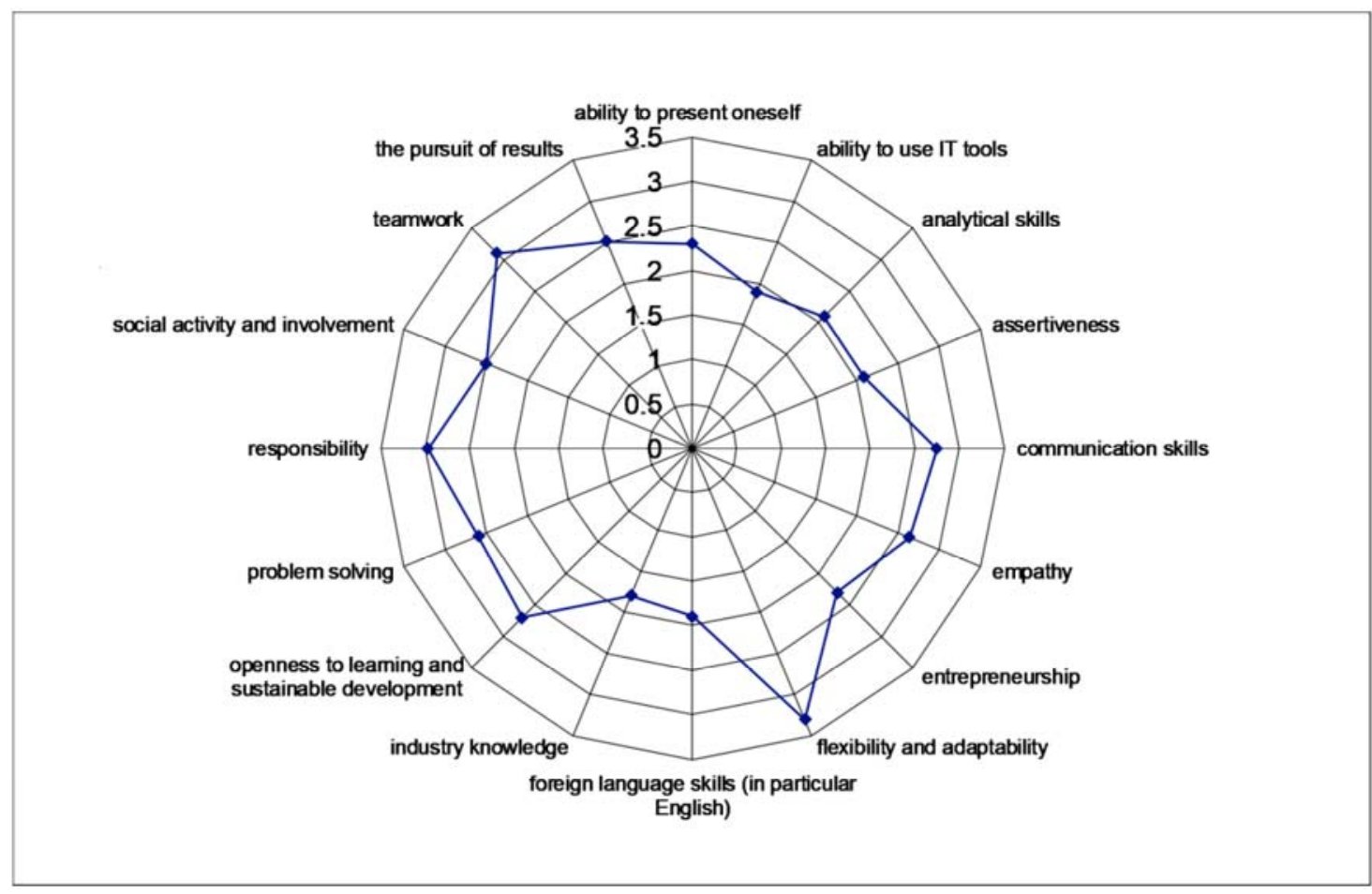

Figure 6. The impact of extracurricular activities on competency development of the respondents.

Although the respondents were not students of the PRME Champions group of universities, the research showed that the competencies identified by the respondents can be referred to the PRME competencies set. Respondents recognized the development of the most relevant competencies, which 
were previously identified by them as the most desirable by the business environment (flexibility and adaptability, responsibility and teamwork, communication skills). One could see consistency between the most important competences for a sustainable environment identified by the respondents and the best developed competencies of the respondents. This allowed us to assume that students and graduates of universities and business schools might be future creators of sustainable values in both business and society.

The respondents positively assessed the extent to which their universities created possibilities to develop their competencies. Most of the answers to this question were positive, but it should be highlighted that some respondents evaluated this level of created opportunities as significant (approx. $9 \%)$, some as sufficient $(37.2 \%)$, or partial $(36.8 \%)$. Only a few respondents assessed it negatively, as paltry $(14.6 \%)$ or non-existent (less than $3 \%)$. Perhaps this negative assessment was related to the passivity of these respondents. They did not use the university's offers in terms of additional activities, were not members of any student organizations, nor took part in social/charitable activities during their studies.

The next question focused on whether those respondents participated in any social/charitable actions during their studies. An affirmative answer was given by $41 \%$ and a negative response by $59 \%$. Engaged respondents later pointed to participation in activities benefiting various stakeholder groups such as the ill (blood donation action), children (Students' Social Responsibility), the poor and needy (preparation of Christmas presents for those in need), animals (Students for Animals), or students (yearly students' festival, Job Fair, Open Day of the university etc.). These activities support a range of student competencies, covering six areas identified by the PRME Champions.

Moreover, the respondents' perception of the competencies most desired by the business environment (and whether they could be developed through involvement in extracurricular activities) was surveyed. Respondents were asked to indicate five competencies that were the most important for the business environment. Among the most important ones (more than one answer was possible), social activity and involvement ( $66.8 \%)$, openness to learn and constant development (52.2\%), ability to work in a team (51\%), responsibility (50.2\%), effective verbal and non-verbal communication $(42.3 \%)$, and flexibility together with the ability to adapt (41.9\%) were mentioned (Figure 7).

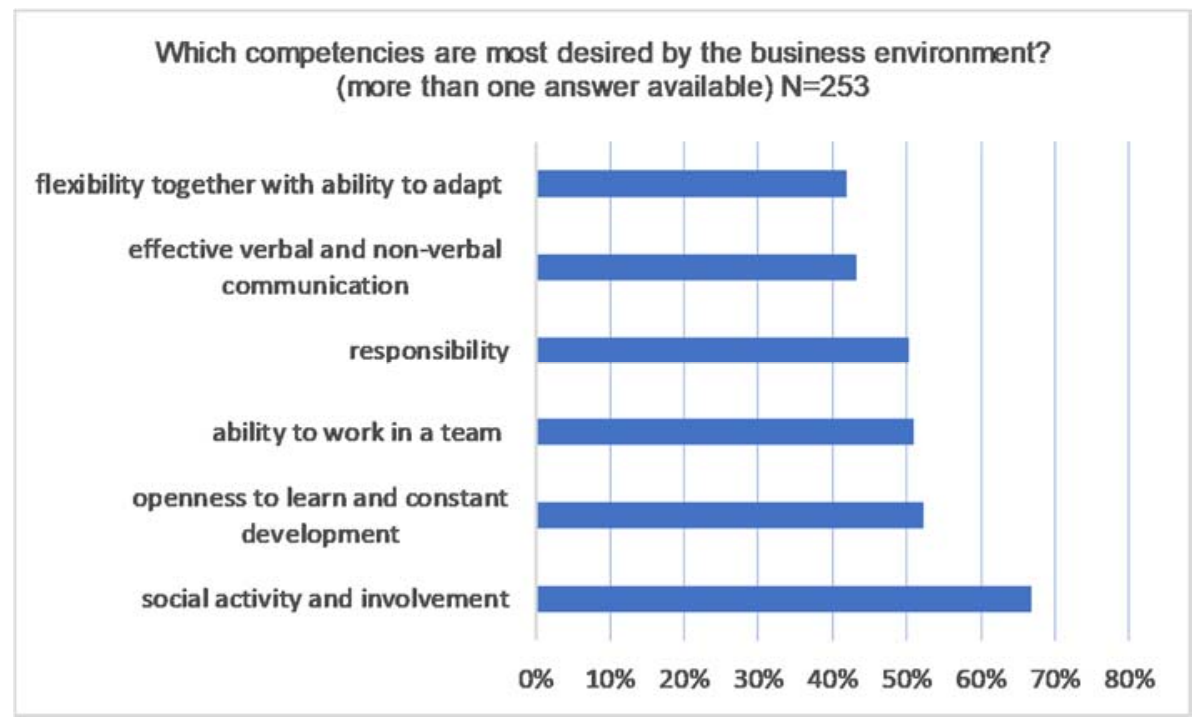

Figure 7. Most desired sustainability-oriented competencies according to business environment.

Based on this analysis, it can be stated that the willingness of Polish students to undertake further education to develop sustainability-oriented competencies is in line with the PRME initiative, which highlights the key role of universities in responsible managerial education (PRME 2018) at every level of study. Universities pursue raising the student awareness of the challenges they face after graduation 
and in their future professional and social lives. Therefore, it is important that this includes courses, training, or majors (including postgraduate and MBA) that offer education concentrated on corporate social responsibility and sustainable development.

\section{Discussion and Conclusions}

James and Card (2012) showed that students were the key actors in diagnosing the perception and participation in practices on sustainability implemented by universities. Educating socially aware citizens and shaping sustainability competencies supports the development of a social and business environment. In particular, it stimulates important skills and attitudes such as creativity, initiative, perseverance, team work, risk understanding, and a sense of responsibility. Students need to be better prepared to face sustainability challenges in all aspects of life and participate in business activities in the future. To support the evolution of the idea of sustainable development, higher education institutions should be reformed through curriculum changes that focus on action-based content, developing competencies associated with social responsibility and sustainability as well as providing multiple possibilities for the social and ecological engagement of students.

Competency development takes place through formal education (courses in the field of social responsibility and sustainable development) and non-formal education (extracurricular, e.g., student organizations, volunteering). It is confirmation of the view that teaching sustainable development requires a multidisciplinary context and a modern approach (Aktas et al. 2014; Sibbel 2009; Cortese 2003; Eizaguirre et al. 2019). Non-formal and informal learning are key elements of gaining experience through culture, youth work, volunteering, or sport. This has been repeatedly emphasized by The Council of the European Union (2018) and is an important element of the pursuit of sustainable development (European Commission 2012).

The goal of the study was to examine how universities developed educational programs to enable students to shape sustainability-oriented competencies. The research analysis included both the university and student perspective. The investigation of Polish universities showed that all of them implemented activities in the area of social responsibility and sustainable development. However, the number and type of curricular and extracurricular activities varied. The universities' programs were addressed to undergraduate and graduate students as well as MBA, postgraduate, and $\mathrm{PhD}$ students. Only three out of 23 analyzed universities had postgraduate studies in CSR or sustainable development. Furthermore, taking into consideration the continuously increasing amount of over 500 international companies' BPO (Business Process Outsourcing) with over 200 thousand employees in Poland (Górecki 2018), there is a great demand for sustainability competencies. While all of these companies have already implemented sustainability or CSR strategies, the conducted research shows that universities have not properly responded to the growing need for CSR and sustainability specialists (Górecki 2018; Responsible Business Forum 2019). As the CSR specialist will be officially included in the classification of occupations and specialties by the Polish Ministry of Family, Labor, and Social Policy in 2020 (Responsible Business Forum 2019), it is expected that there will be a larger demand for specialists in this profession.

Another objective of this study was to investigate if students actually engaged in activities related to sustainable development offered by the universities and how they perceived competency development through non-formal education. The research showed that one in two respondents engaged in additional activities offered by the universities. Moreover, the respondents well assessed the level of their sustainability competencies gained during their studies. These competencies included flexibility with the ability to adapt, openness to learning and continuous development, teamwork and responsibility, effective verbal and non-verbal communication, and the ability to formulate and solve problems. These skills are useful regardless of the occupation or industry and their high level affects both the learning outcomes of the students and the labor market (Deming 2015; Heckman and Kautz 2012). Furthermore, the respondents' perception about the competencies most desired by the 
business environment (and if they could be developed through involvement in activities from outside the study program) also enriched the analysis.

Coherence could be also observed between the most important competencies for sustainable development and the best developed competencies of the respondents. The best developed competencies through the extracurricular activities offered by the universities are indicated in Figure 5 . These competencies largely conform with the PRME framework:

A. Social skills: teamwork, team building, communication skills, presentation, assertiveness, flexibility and adaptability

B. Business in the real world: social activity and involvement, openness to learning and sustainable development, entrepreneurship, ability to use IT tools, industry knowledge;

C. Personal skills: critical thinking, self-awareness, decision making, leadership, creativity, problem solving, the pursuit of results, flexibility and adaptability, openness to learning and sustainable development, analytical skills, ability to present oneself;

D. Intercultural skills, flexibility and adaptability, foreign language skills;

E. Academic research, business models, planning and coordination, the pursuit of results, openness to learning and sustainable development, ability to use IT tools; and

F. Service, volunteering, empathy, social responsibility, global mindset, ethical awareness, empathy, social activity and involvement, responsibility.

This allows us to assume that university students will be active promoters of sustainable values for business and society. The implementation of the UN PRME initiative certainly enables the achievement of this goal. Its principles and values are increasingly being adopted by business schools around the world as a framework for various programs and activities (Prandi et al. 2018). Promoting social, economic, and political transformation begins with changes in individual behavior that will translate into a better and more sustainable future for all people.

The PRME framework is also applicable when applying for various job positions (especially managerial or relations-oriented) because soft skills often play a priority role. According to the report presented by the Warsaw School of Economics, the American Chamber of Commerce in Poland, and Ernst \& Young entitled "Competencies and qualifications sought among graduates of higher education on the labor market", the most important criteria considered by the company while recruiting university graduates are personal and interpersonal competencies, with the emphasis on ethical and sustainable attitude and engagement (Ernst \& Young 1012). These competencies, as indicated by numerous researchers, will be also important in the future. McKinsey \& Company (2018), in cooperation with the monthly "Forbes Polska", prepared a report entitled "Arm in arm with the robot. How to use the potential of automation in Poland", which examined the impact of automation on the Polish economy and the labor market as well as outlining the key challenges and opportunities that it entails. The report emphasized the fact that key skills for the future labor market will be soft skills such as creativity, team work, empathy, critical thinking, problem solving, and the use of technical knowledge with the assistance of technology. Similar observations have appeared in other analysis (World Bank 2016; World Economic Forum 2018) which list problem solving, critical thinking, creativity, team work and team management as well as emotional intelligence among the key skills in the future labor market. Experts point out that skills identified in this article can be learned and that their high level improves both learning outcomes and the job market (Deming 2015; Heckman and Kautz 2012).

The results of this study have practical implications. Polish public universities offer students a wide range of opportunities to develop sustainability competencies. Two thirds of students believe that there are many opportunities offered by the universities which include, among others, membership in student organizations, sports, international, scientific and charity organizations, volunteering, and other additional activities. Participation in various types of organizations and projects enables the development of a number of competencies grouped in the PRME competencies set. These include social skills such as teamwork or communication skills, cooperation and stakeholder management, and the 
strengthening of sustainable development or social awareness. Sustainability-oriented competencies are perceived by many scientists as a determinant of the effectiveness of an individual's functioning in society (e.g., Argyle 1983; Goleman 2006; Borkowski 2003). In turn, a number of available analyses and reports (e.g., World Economic Forum 2018, McKinsey \& Company 2018; World Bank 2016; Ernst \& Young 1012) emphasize that soft skills such as creativity, teamwork, empathy, critical thinking, or problem solving will be the key skills for the future labor market. Volunteering and other forms of charitable activities are important elements of shaping competencies that enable an active creation of the future. Volunteering shapes the acquisition of competencies by empirical or rather random learning. Individuals start to get involved and then face obstacles. They have to cope with different tasks, although they are not sure whether they are dealing with them because they have absolutely no experience, and try to develop problem solving strategies themselves (Barth et al. 2007). Such activities help young people to be creative, confident, and socially responsible as well as shape attitudes such as honesty, responsibility, self-esteem, sustainability, entrepreneurship, and readiness to take initiatives in teamwork or citizenship.

Even though the universities have developed educational programs and non-curricular activities, they still lack a market-oriented offer for postgraduate professionals. There is also a necessity for practical workshops, projects with companies, and business-oriented learning approaches that could enhance the process of shaping students' competencies more effectively than regular classes. Solving real-life problems during classes enables students to be more prepared for future challenges. This shows that cooperation between Polish universities and business representatives as well as NGOs should be strengthened and might largely enrich the study program and extracurricular activities. Partnerships for sustainable development with other universities as well with the business environment, NGOs, public administration agendas, and the media might create a common network of mutual support and a platform for knowledge exchange and dialogue. According to the old Chinese proverb "Tell me and I forget. Show me and I remember. Involve me and I understand." (Ochiai 1993), universities should implement innovative teaching methods and educational approaches that will transform sustainable development education from the system of supporting superficial knowledge into an action-based learning system. In this context, it is important to place emphasis on sharing knowledge, research, and good practices in order to promote sustainable development at universities.

By considering the above-mentioned findings and implementing them into a PRME framework, there are different possible implications for Polish universities, which may also be applicable for other countries. First, given the educational offers of Polish universities providing business studies, it is important to develop a holistic approach to implementing the idea of sustainable development in the curriculums. The sustainability issues should not only be limited to courses on corporate social responsibility, but it is important to include these issues across a broad range of courses in different fields. Universities should largely focus on the development of the ability of students to be leaders of change in the field of sustainable development and social responsibility (Hesselbarth and Schaltegger 2014). Competencies related to sustainable development (such as critical thinking, problem solving, team work, communication and negotiation skills, analytical skills, creativity and intercultural skills) are useful in all areas of professional and private life.

Another issue is related to making universities aware of the student and market needs in the area of sustainable development competencies and diagnosing the gap between educational offers and student needs in the scope of sustainable development. As the CSR specialist is officially becoming a profession, the development of these competencies will be also more important in the future, especially for postgraduate and MBA students. The research has shown that this type of activity is not well prepared and does not meet market needs. Furthermore, it is important to further analyze what the market expectations are and how to create a framework that could help to educate those specialists.

This research has shown the necessity to study formal and non-formal (extracurricular) education separately. Underestimation of non-formal education by universities can be a mistake, leading to the inability to adapt to sustainable development educational needs. The study also points to the 
need to create a better communication platform between universities and students. In order to equip students with the necessary knowledge, skills, and competencies for sustainable development, universities need to make sure that students are well informed about the formal and non-formal educational activities on offer. Universities constitute a mechanism for sustainable development and need to adequately communicate the necessary conditions for effective sustainable change (Disterheft et al. 2013; Leal Filho 2012).

This study has several limitations. The research analysis was conducted under the specific context of Polish higher education institutions, although the theoretical reasoning and recommendations are not specific to this context. There is also a limitation in the research design caused by the convenience sampling method, which is related to collecting data from population members who were conveniently available for participation in this study. Due to an under-representation of the research sample, this research cannot be generalized to the entire population of students in Poland.

This article contributes to an important discussion about the key sustainability competencies. Based on the above considerations, this study may have broader implications intended to highlight the importance of the development of sustainability competencies at universities. This research is the first to study sustainable development-oriented educational programs on offer among Polish universities and highlights the need to continue studying the role of universities in the development of competencies on a broader scale. The investigated Polish case can be replicated to analyze other universities in Poland as well as in other countries by focusing on the role of sustainability competencies in education. Incorporating sustainable development issues into the university's strategy can provide a better understanding of the role of universities in shaping sustainability competencies.

Finally, the conducted analysis enhances the theoretical understanding of the role of universities in education for sustainable development. This study contributes to the literature on sustainable development competencies by highlighting the role of formal and non-formal education in this field.

Author Contributions: Conceptualization, formal analysis, investigation, methodology, writing—original draft, M.S. and A.Ż.; Research of universities, K.R.; Validation, project administration, supervision writing-review and ending, M.S.

Funding: This research received no external funding.

Acknowledgments: The authors would like to thank the respondents who participated in the research. Our deep gratitude also goes to the anonymous reviewers for their helpful comments and constructive feedback on earlier versions of this paper.

Conflicts of Interest: The authors declare no conflicts of interest.

\section{References}

AACSB. 2009. Eligibility Procedures and Accreditation Standards for Business Accreditation. Tampa: Association to Advance Collegiate Schools of Business.

Aktas, Can B., Rosemary Whelan, Howard Stoer, Edmund Todd, and Cindy L. Kern. 2014. Developing a university-wide course on sustainability: A critical evaluation of planning and implementation. Journal of Cleaner Production 106: 216-21. [CrossRef]

Argyle, Michael. 1983. The Psychology of Interpersonal Behaviour, 4th ed. Penguin Press: New York.

Babbie, Earl R. 2013. The Practice of Social Research, 13th ed. Wadsworth Publishing: Belmont.

Barth, Matthias, Jasmin Godemann, Marco Rieckmann, and Ute Stoltenberg. 2007. Developing key competencies for sustainable development in higher education. International Journal of Sustainability in Higher Education 8: 416-30. [CrossRef]

Beyond Grey Pinstripes. 2009. Aspen's Global 100: Beyond Grey Pinstripes. 2009-10. Washington: Aspen Institute. Blasco, Maribel. 2012. Aligning the Hidden Curriculum of Management Education with PRME: An Inquiry-Based Framework. Journal of Management Education 36: 364-88. [CrossRef]

Borkowski, Jan. 2003. Podstawy Psychologii Społecznej. Warszawa: Dom Wydawniczy ELIPSA. 
Boström, Magnus, Erik Andersson, Monika Berg, Karin Gustafsson, Eva Gustavsson, Erik Hysing, Rolf Lidskog, Erik Löfmarck, Maria Ojala, Jan Olsson, and et al. 2018. Conditions for Transformative Learning for Sustainable Development: A Theoretical Review and Approach. Sustainability 10: 4479. [CrossRef]

Brito, Rosa Maria, Columba Rodriguez, and Jose Luis Aparicio. 2018. Sustainability in Teaching: An Evaluation of University Teachers and Students. Sustainability 10: 439. [CrossRef]

Brundtland, Gro Harlem. 1987. Our Common Future, Report of the World Commission on Environment and Development. Oxford: Oxford University Press, p. 37.

Cameron, Kim. 2011. Responsible leadership as virtuous leadership. Journal of Business Ethics 98: 25-35. [CrossRef]

Cerone, Antonio, and Donatella Persico. 2014. Innovation and Sustainability in Education. SEFM 2012 Satellite Events, LNCS 7991. Berlin: Springer, pp. 3-16.

Cook, Thomas D., and Donald T. Campbell. 1979. Quasi-Experimentation: Design and Analysis Issues for Field Settings. Boston: Houghton Mifflin.

Cortese, Anthony D. 2003. The critical role of higher education in creating a sustainable future. Planning for Higher Education 31: 15-22.

Crowther, David, and Geoffrey Lancaster. 2008. Research Methods: A Concise Introduction to Research in Management and Business Consultancy, 2nd ed. New York: Taylor \& Francis.

De Block, Liesbeth, and David Buckingham. 2007. Global Children, Global Media: Migration, Media and Childhood. London: Palgrave.

De Haan, Gerhard. 2010. The development of ESD-related competencies in supportive institutional frameworks. International Review of Education 56: 315-28. [CrossRef]

Deming, David J. 2015. The Growing Importance of Social Skills in the Labor Market. Working Paper No. 21472. Cambridge: National Bureau of Economic Research.

Disterheft, Antje, Sandra Caeiro, Ulisses Azeiteiro, and Walter Leal Filho. 2013. Sustainability Science and Education for Sustainable Development in Universities: Away for Transition. In Sustainability Assessment Tools in Higher Education Institutions: Mapping Trends and Good Practices around the World. Cham: Springer International Publishing Switzerland, pp. 3-28.

Eizaguirre, Almudena, Maria García-Feijoo, and Jon Paul Laka. 2019. Defining Sustainability Core Competencies in Business and Management Studies Based on Multinational Stakeholders' Perceptions. Sustainability 11: 2303. [CrossRef]

EQUIS. 2010. EQUIS Standards E Criteria. Brussels: European Quality Improvement System. Available online: https://efmdglobal.org/wp-content/uploads/EFMD_Global-EQUIS_Standards_and_Criteria.pdf (accessed on 16 May 2019).

Ernst \& Young. 1012. Kompetencje i kwalifikacje poszukiwane przez pracodawców wśród absolwentów szkół wyższych wchodzacych na rynek pracy. Available online: http://firma.sgh.waw.pl/pl/Documents/RKPK_ raport_2012.pdf (accessed on 6 May 2019).

Erpenbeck, John, and Lutz von Rosenstiel. 2003. Handbuch Kompetenzmessung. Erkennen, verstehen und bewerten von Kompetenzen in der betrieblichen, pädagogischen und sychologischen Praxis. Stuttgart: Schäffer-Poeschel.

European Commission. 2012. Proposal for a Council Recommendation on the Validation of Non-Formal and Informal Learning. Brussels: European Commission.

European Union. 2010. Europe 2020 A European Strategy for Smart, Sustainable and Inclusive Growth. Brussels: European Union.

Ghoshal, Sumantra. 2005. Bad management theories are destroying good management practices. Academy of Management Learning and Education 4: 75-91. [CrossRef]

Goleman, Daniel. 2006. Emotional Intelligence. New York: Random House Publishing Group.

Gond, Jean-Pascal, Jacques Igalens, Valerie Swaen, and Assaad El Akremi. 2011. The human resources contribution to responsible leadership: An exploration of the CSR-HR interface. Journal of Business Ethics 98: 115-32. [CrossRef]

Górecki, Janusz. 2018. Sektor nowoczesnych usług biznesowych w Polsce. ABSL Report. Available online: https://absl.pl/wp-content/uploads/2018/06/raport_absl_2018_PL_180527_epub-1.pdf (accessed on 8 May 2019).

Groves, Kevin S., and Michael LaRocca. 2011. Responsible leadership outcomes via stakeholder CSR values: Testing a values-centered model of transformational leadership. Journal of Business Ethics 98: 37-55. [CrossRef]

Heckman, James J., and Tim Kautz. 2012. Hard Evidence on Soft Skills, Labour Economics 19: 451-64. [PubMed] 
Hesselbarth, Charlotte, and Stefan Schaltegger. 2014. Educating change agents for sustainability-Learnings from the first sustainability management master of business administration. Journal of Cleaner Production 62: 24-36. [CrossRef]

Holfelder, Anne-Katrin. 2019. Towards a sustainable future with education? Sustainability Science 14: $943-52$. [CrossRef]

Jamali, Dima. 2016. Opportunities and Challenges for CSR Mainstreaming in Business Schools. International Journal of Technology and Educational Marketing 6: 1-29. [CrossRef]

James, Matthew, and Karen Card. 2012. Factors contributing to institutions achieving environmental sustainability. International Journal of Sustainability in Higher Education 13: 166-76. [CrossRef]

Kalinowska, Anna, and Anna Batorczak. 2017. Uczelnie wyższe wobec wyzwań celów zrównoważonego rozwoju. Zeszyty Naukowe Politechniki Ślaskiej, Seria: Organizacja i Zarządzanie z 104: 281-90.

Kudłak, Robert, and Kathleen Y. J. Low. 2015. Special Issues Dedicated to CSR and Corporate Sustainability: A Review and Commentary. Long Range Planning 48: 215-27. [CrossRef]

Lackéus, Martin. 2015. Entrepreneurship in Education: What, Why, When, How. Long Range Planning 48: $215-27$.

Lambrechts, Wim, Ingrid Mulà, Kim Ceulemans, Ingrid Molderez, and Veerle Gaeremynck. 2013. The integration of competences for sustainable development in higher education: An analysis of bachelor programs in management. Journal of Cleaner Production 48: 65-73. [CrossRef]

Leal Filho, Walter. 2012. Sustainable Development at Universities, 2nd ed. Frankfurt: Peter Lang.

Lozano, Rodrigo, Michelle Y. Merrill, Kaisu Sammalisto, Kim Ceulemans, and Francisco J. Lozano. 2017. Connecting Competences and Pedagogical Approaches for Sustainable Development in Higher Education: A Literature Review and Framework Proposal. Sustainability 9: 1889. [CrossRef]

McKinsey \& Company. 2018. Arm in Arm with the Robot. How to Use the Potential of Automation in Poland. Report. Available online: https://mckinsey.pl/wp-content/uploads/2018/05/Rami\%C4\%99-w-rami\%C4\%99-zrobotem_Raport-McKinsey.pdf (accessed on 8 May 2019).

Miotto, Giorgia, Alicia Blanco González, and Cristina Del Castillo Feito. 2018. Social Responsibility: A Tool for Legitimation in Spanish Universities' Strategic Plans. Trípodos 42: 59-79.

Mochizuki, Yoko, and Zinaida Fadeeva. 2010. Competences for Sustainable Development and Sustainability. International Journal of Sustainability in Higher Education 11: 391-403. [CrossRef]

Ochiai, El-Ichiro. 1993. Ideas of equality and ratio: Mathematical basics for chemistry and the fallacy of unitary conversion. Journal of Chemical Education 70: 44-46. [CrossRef]

Owens, Linda K. 2002. Introduction to Survey Research Design. Available online: http://www.srl.uic.edu/seminars/ Intro/introsrm.pdf (accessed on 12 November 2018).

Polish Ministry of Science and Higher Education. 2019. List of Public Universities Supervised by the Minister Competent for Higher Education. Available online: https://www.gov.pl/web/nauka/wykaz-uczelnipublicznych-nadzorowanych-przez-ministra-wlasciwego-ds-szkolnictwa-wyzszego-publiczne-uczelnieakademickie (accessed on 15 March 2019).

Prandi, Maria, Janette Martell, and Josep M. Lozano. 2018. Learning in a Social Context. Available online: http://www.unprme.org/resource-docs/LearninginaSocialContextReport.pdf (accessed on 20 May 2019).

PRME. 2018. Search Participants, Principles for Responsible Management Education. Available online: http: //www.unprme.org/participation/index.php (accessed on 20 May 2019).

PRME. 2019. About the PRME Initiative. Available online: https://www.unprme.org/news/index.php?newsid= 359\#.XUy3RegzbIV (accessed on 20 May 2019).

Ramos, Gabriela I. 2016. The Sustainable Development Goals: A duty and an opportunity. In Love P. Debate the Issues: New Approaches to Economic Challenges. Paris: OECD Publishing, pp. 17-21.

Responsible Business Forum. 2019. Specjalista/ka ds. CSR oficjalnie znajdzie się na liście zawodów Ministerstwa Rodziny, Pracy i Polityki Społecznej. Available online: http://odpowiedzialnybiznes.pl/aktualno\%C5\%9Bci/ specjalista-ka-ds-csr-oficjalnie-na-liscie-zawodow-ministerstwa-rodziny-pracy-i-polityki-spolecznej/ (accessed on 8 May 2019).

Roorda, Niko. 2010. Sailing on the Winds of Change: The Odyssey to Sustainability of the Universities of Applied Sciences in The Netherlands. Maastricht: Maastricht University.

Salvioni, Daniela M., Simona Franzoni, and Raffaella Cassano. 2017. Sustainability in the Higher Education System: An Opportunity to Improve Quality and Image. Sustainability 9: 914. [CrossRef] 
Sammalisto, Kaisu, Agneta Sundström, and Tove Holm. 2015. Implementation of sustainability in universities as perceived by faculty and staff-A model from a Swedish University. Journal of Cleaner Production 106: 45-54. [CrossRef]

Setó-Pamies, Dolores, and Eleni Papaoikonomou. 2016. A Multi-level Perspective for the Integration of Ethics, Corporate Social Responsibility and Sustainability (ECSRS) in Management Education. Journal of Business Ethics 136: 523-38. [CrossRef]

Sibbel, Anne. 2009. Pathways towards sustainability through higher education. International Journal of Sustainability in Higher Education 10: 68-82. [CrossRef]

Sims, Ronald R., and Edward L. Felton. 2005. Teaching business ethics: Targeted outputs. Journal of Business Ethics 60: 377-91.

Szreder, Mirosław. 2004. Metody i techniki sondażowych badań opinii. Warszawa: PWE.

Tarozzi, Massimiliano, and Carla Inguaggiato. 2016. Global Citizenship Education in Europe, A Comparative Study of Education Policies across 10 EU Countries. Available online: https://www.varianty.cz/download/ docs/3379_a-research1-part-1-09-01.pdf (accessed on 22 May 2019).

The Council of the European Union. 2018. COUNCIL RECOMMENDATION of 22 May 2018 on Key Competences for Lifelong Learning. 2018/C 189/01. Available online: https://eur-lex.europa.eu/legal-content/EN/TXT/PDF/ ?uri=CELEX:32018H0604(01)\&from=EN (accessed on 22 May 2019).

UNESCO. 2014. UNESCO Roadmap for Implementing the Global Action Programme on Education for Sustainable Development. Available online: https://sustainabledevelopment.un.org/content/documents/ 1674unescoroadmap.pdf (accessed on 1 May 2019).

UNESCO. 2017. Education for Sustainable Development Goals: Learning Objectives. Paris: UNESCO. Available online: http://unesdoc.unesco.org/images/0024/002474/247444e.pdf (accessed on 15 April 2019).

United Nations. 2015. Transforming Our World: The 2030 Agenda for Global Action. Available online: https: //sustainabledevelopment.un.org/post2015/transformingourworld/publication (accessed on 1 May 2019).

Urbaniec, Maria. 2018. Kształtowanie kompetencji studentów zgodnie z zasadami odpowiedzialnej edukacji menedżerskiej. Horyzonty Wychowania 17: 167-76.

Weinert, Franz Emanuel. 2001. Concept of competence: A conceptual clarification. In Defining and Selecting Key Competencies. Edited by Dominique Simone Rychen and Laura Hersh Salganik. Seattle: Hogrefe and Huber, pp. 45-66.

World Bank. 2016. World Development Report 2016: Digital Dividends. Available online: http://documents. worldbank.org/curated/en/896971468194972881/pdf/102725-PUB-Replacement-PUBLIC.pdf (accessed on 8 May 2019).

World Economic Forum. 2018. The Future of Jobs: Employment, Skills, and Workforce Strategy for the Fourth Industrial Revolution, Renew Europe. Available online: http://www3.weforum.org/docs/Renew_Europe_ report_2018.pdf (accessed on 8 May 2019).

Żur, Agnieszka. 2016. Edukacja spersonalizowana a rozwijanie potrzebnych współcześnie kompetencji społecznych wśród studentów uczelni wyższych. Horyzonty Wychowania 15: 137-55.

(C) 2019 by the authors. Licensee MDPI, Basel, Switzerland. This article is an open access article distributed under the terms and conditions of the Creative Commons Attribution (CC BY) license (http://creativecommons.org/licenses/by/4.0/). 